\title{
Construction and screening of BAC libraries made from Brachypodium genomic DNA
}

\author{
Kerrie Farrar \& Iain S Donnison \\ Institute of Grassland and Environmental Research, Plas Gogerddan, Aberystwyth SY23 4AR, UK. Correspondence should be addressed to I.S.D. \\ (iain.donnison@bbsrc.ac.uk).
}

Published online 28 June 2007; doi:10.1038/nprot.2007.204

Bacterial artificial chromosome (BAC) libraries are the large DNA insert libraries of choice and valuable tools for the map-based cloning of target quantitative trait loci, physical mapping, molecular cytogenetics and comparative genomics. The protocol reported here is a simplified method used to produce and screen BAC libraries from Brachypodium species and other related grasses. Intact nuclei, containing high molecular weight (HMW) DNA, are isolated and embedded in agarose plugs. The HMW DNA is digested using an appropriate restriction enzyme and size-fractionated using pulsed-field gel electrophoresis. The DNA is isolated by dialysis, ligated into pre-prepared vector and electroporated into competent Escherichia coli cells. A PCR-based method for screening the library is also described. The entire protocol takes at least 6 weeks to complete.

\section{INTRODUCTION}

Bacterial artificial chromosomes (BACs) are the vectors of choice for large insert libraries. Compared with the main alternative, yeast artificial chromosomes, they are easy to handle, and the clones are stable and are less likely to be chimeric. Importantly, DNA purification and sequencing from BACs is simple and straightforward. BAC libraries provide a platform for the creation of physical maps and complete genome sequencing, which are powerful tools for large-scale gene discovery and elucidation of gene function and regulation ${ }^{1-3}$. BAC libraries are also important for map-based cloning of quantitative trait loci, molecular cytogenetics and comparisons of specific regions between different species or ecotypes, including establishment of synteny and functional single nucleotide polymorphism (SNP) analyses in coding and regulatory sequences.

Brachypodium was first proposed as a model species by Draper et al. ${ }^{4}$ in 2001 as it is a member of the agronomically important Pooidae, closely related to the temperate cereals and the meadow and forage grasses. It is also a suitable model for developing a range of grass species as energy crops. With both plant and genome sizes comparable to Arabidopsis, Brachypodium displays many characteristics ideal for a model species, including inbreeding, high recombination, a short life cycle and an absence of seed drop. It has undemanding growth requirements, and fertile plant regeneration is possible via somatic embryogenesis, making it amenable to highthroughput genetics and mutant screens ${ }^{4}$. To facilitate the exploitation of Brachypodium as a model species it is important to generate genetic tools. Brachypodium is readily transformed either by microprojectile bombardment of somatic embryonic callus or by Agrobacterium $^{5,6}$, and a large number of expressed sequence tags (ESTs) have been generated and assigned tentative classification by homology and orthology ${ }^{7}$. Comparative fluorescent in situ hybridization methods have been developed to study genome organization $^{8,9}$, and mutagenesis by sodium azide has been achieved ${ }^{10}$. To supplement these tools we here describe a simple and robust method for the generation of a BAC library for Brachypodium. This protocol has been used successfully to generate libraries from Brachypodium distachyon (Brachypodium) ${ }^{11}$ and related grass species, including Lolium perenne ${ }^{12}$, Festuca pratensis ${ }^{13}$ and Paspalum simplex ${ }^{14}$.
The preparation of plant nuclei, embedded in agarose plugs for ease of manipulation, is performed essentially as described by Zhang et al. ${ }^{15}$ and Choi et al. (http://www.cco.caltech.edu/ schoi/ Mega.html). Other protocols ${ }^{16-19}$ differ in detail from the method described here. For example, Chalhoub et al. ${ }^{18}$ suggest reducing the amount of DNA for partial digestion to $5 \mu \mathrm{g}$, performing electrophoresis in $0.25 \times$ Tris-borate-EDTA (TBE) and performing a triple size selection in order to generate consistently large inserts with higher transformation efficiency.

\section{Experimental design}

Issues that should be considered when designing the experiment are discussed below.

Insert size. The target average insert size is a major consideration when making a library. Large fragments (greater than $125 \mathrm{~kb}$ ) result in either greater coverage with a given number of clones or a smaller number of clones (and hence less freezer space) being required for a given coverage library. Large inserts are preferable for generating contigs but are more difficult to handle and directly sequence than smaller inserts (less than $125 \mathrm{~kb}$ ), which facilitate walking to a gene of interest. It should also be noted that there is an inverse relationship between transformation efficiency and insert size. In addition, it would appear that insert size is to some extent species specific; for example, BAC libraries with an average insert size of between 88 and $150 \mathrm{~kb}$ in different species have been constructed using the protocol described here.

Choice of restriction enzyme. Another consideration is the choice of restriction enzyme used to generate the library. HindIII and $B a m \mathrm{HI}$ are the conventional choices using commercially available BAC vectors as they are both common enzymes that generate a good distribution of suitably sized fragments throughout the genome. In cases where a single enzyme is suspected to be under-represented in certain genomic regions, it is desirable to generate a library using a combination of at least two enzymes. This is an important consideration if the BAC library is to be used in the construction of a physical map. 
Figure 1 | Example of a trial digestion of high molecular weight (HMW) DNA in agarose plugs with $0,0.1,0.2,0.5,1,2,5$ or $10 \mathrm{U}$ of HindIII restriction enzyme per half-plug. After incubation in restriction buffer and enzyme on ice for $4 \mathrm{~h}$, the HMW DNA was restricted by incubation at $37^{\circ} \mathrm{C}$ for $1 \mathrm{~h}$. The reaction was stopped by addition of Tris-borate-EDTA (TBE) buffer and the plugs loaded on an agarose gel and subjected to pulsed-field gel electrophoresis (PFGE). The left- and right-most lanes contain the HMW lambda ladder (NEB, Beverly, MA). The bottom three bands migrate at $145.5,97.0$ and $48.5 \mathrm{~kb}$.

Restriction enzyme concentration. To determine the optimum concentration of restriction enzyme required to make the library, consideration should be given to the intended use of the library. For smaller inserts select a restriction enzyme concentration giving the highest concentration of DNA in the 100-120-kb region. However, for larger inserts it is recommended that a restriction enzyme concentration is chosen that does not generate a large concentration of DNA below $100 \mathrm{~kb}$, even if this means there is less DNA in the desired 120-150-kb region of the gel. In all cases gel slices 20-50 kb higher than the desired average insert size should be taken. For smaller inserts a single size selection is sufficient and will yield the greatest number of clones; however, a second size selection is recommended for the selection of larger inserts to remove contaminating short fragments, which will preferentially ligate to the vector. With reference to Figure 1, $0.5 \mathrm{U}$ would be selected to generate the maximum number of inserts at $100 \mathrm{~kb}$, whereas $0.2 \mathrm{U}$ would be selected to generate larger inserts. Please note that each new batch of plugs requires a test digest; results from one cannot be applied to another. When restriction enzyme digestion is performed on intact plugs, twice the optimal enzyme concentration determined by the half-plug test experiment should be used.

Choice of vector. Pre-prepared vector such as pIndigoBAC5 (Epicentre) is available pre-digested with HindIII or Bam HI and dephosphorylated, and is strongly recommended. This and other standard BAC vectors are based on the pBeloBACII vector ${ }^{20}$, which is in turn based on the pBAC108L vector designed by Shizuya et al. ${ }^{1}$ with the additional feature of the $l a c Z$ gene, which allows identification of transformants with and without inserts by colony color (blue/white selection), although in our experience the cloning efficiency is such that this step is not required. If, however, blue/ white selection is required, addition of isopropyl-beta-D-thiogalactopyranoside (IPTG) and Xgal to the Luria Bertani (LB)-agar plates is necessary (see REAGENT SETUP).

One feature of standard BAC vectors is that they are very low copy number, resulting in low DNA yield from BAC preps. Frengen et al. ${ }^{21}$ describe a vector named pBACe3.6 in which the $\mathrm{P} 1$ replicon is replaced with a high copy number replicon from pUC19 to increase plasmid copy numbers and hence increase DNA yields. This vector also contains multiple cloning sites located within the levansucrase $(s a c B)$ gene, allowing positive selection for recombinant BAC clones by the addition of sucrose to the growth medium instead of blue/white selection. More recently, Wild et al. ${ }^{22}$ have described conditionally amplifiable ( $\mathrm{pBAC} / \mathrm{oriV}$ ) BAC vectors that retain the advantages of low copy number $B A C$ vectors but include a conditional oriV/TrfA amplification system that allows up to 100 copies of the vector per host cell under induction conditions. Variations on this vector (pEZ BAC and pSMART) are now commercially available pre-cut and dephosphorylated ready for use from Lucigen (Middleton, WI).

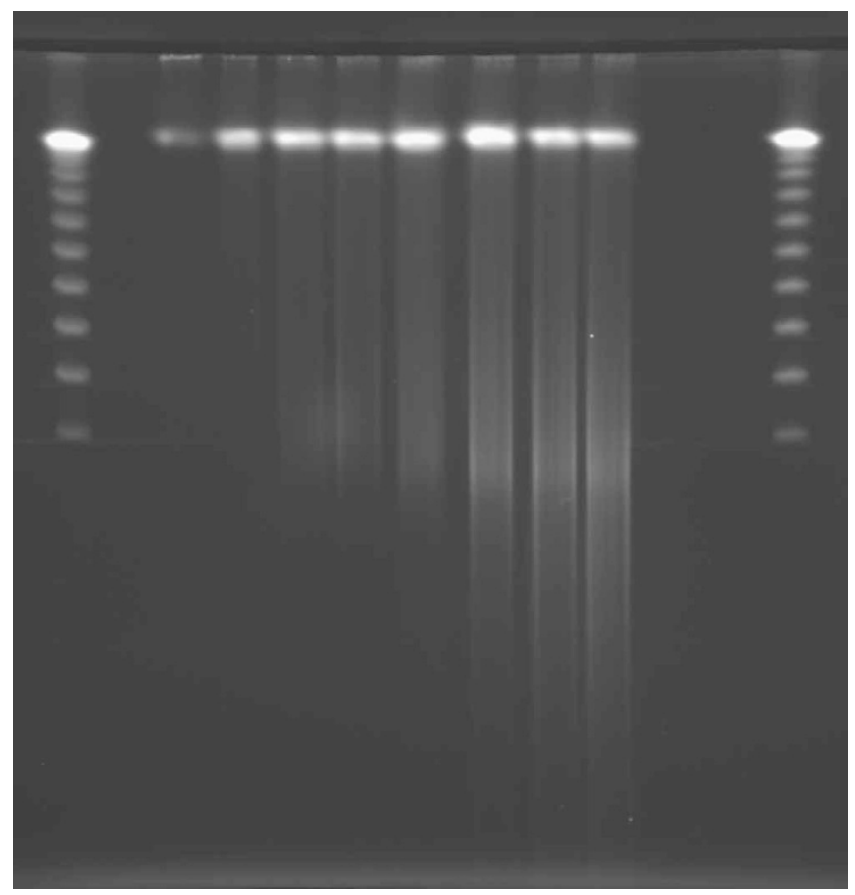

Plant transformation-competent BACs [binary BACs (BIBACs)] that allow direct transformation of a plant with the BAC of interest without further cloning have been described both using a modified binary vector ${ }^{23}$ and by conversion of conventional BACs to BIBACs $^{24}$. Despite a reported Arabidopsis BIBAC library with an average insert size of more than $160 \mathrm{~kb}^{25}$, Song et al. ${ }^{26}$ found potato DNA fragments larger than $100 \mathrm{~kb}$ to be unstable in Agrobacterium, thus seriously undermining the usefulness of the method.

Alternative BAC vectors have been described (see $\mathrm{She}^{27}$ for review). For further information on making your own BAC vector, see ref. 27 and http://www.tree.caltech.edu/protocols/BAC_lib_ construction.html.

Transformation efficiency. Unlike transformation of DNA fragments up to $7 \mathrm{~kb}$, the efficiency of electroporation with large DNA fragments is highly dependent on the strain of Escherichia coli used, and in all cases transformation efficiency drops with increasing size of DNA. Different voltage gradients and time constants may be required for maximum transformation of large molecules with respect to smaller $\mathrm{DNA}^{28}$. It should be noted that the pUC19 control supplied with most electrocompetent cells is therefore not a suitable transformation control for optimization of BAC transformation efficiency. Electrocompetent cells (E. cloni 10G BAC optimized) designed exclusively for vectors containing large inserts such as BACs are now commercially available from Lucigen and are supplied with control insert DNA.

Library screening. To enable rapid screening of the BAC library it is desirable to set up a PCR-based screen. A number of options exist, but a simple screen will be described below based on pools that identify a single 96-well plate of clones after a single round of PCR. A major determinant of the system used will be the number of BAC clones in the library. DNA pools of 96-well microtiter plategrown BAC clones were generated to enable a PCR-based screen of the library. Enough clones were generated to fill 343 96-well 
TABLE 1 | Chloroplast gene primers. Primer names and sequences for testing chloroplast DNA contamination of the BAC library using three chloroplast gene targets (see Step 69).

\begin{tabular}{lll}
\hline Primer & Sequence $\left(\mathbf{5}^{\prime}\right.$ to $\left.\mathbf{3}^{\prime}\right)$ & Gene target of primer \\
\hline $5 \mathrm{ndh}$ & ggg tag agg tag aaa cta tc & NADH dehydrogenase \\
$3 \mathrm{ndh}$ & cgc ttc tga att gat ctc atc c & NADH dehydrogenase \\
$5 \mathrm{psb}$ & gga agc tgc atc tgt tga tg & Photosystem II protein \\
$3 \mathrm{psb}$ & agg gaa gtt gtg agc att acg & Photosystem II protein \\
$5 \mathrm{rbcL}$ & $\mathrm{ctg}$ ata ctt ggc agc att cc & Ribulose-1,5-bisphosphate carboxylase large subunit \\
$3 \mathrm{rbcL}$ & cga tta gct gct gca cca g & Ribulose-1,5-bisphosphate carboxylase large subunit \\
\hline
\end{tabular}

microtiter plates, which would enable the use of a 3D $7 \times 7 \times 7$ microtiter plate grid as the basis for the screen. Assuming BACs with an average insert size of $100 \mathrm{~kb}$ and, for example, a B. distachyon haploid genome size of $355 \mathrm{Mb}^{29}, 3,500$ clones are required for each genome equivalent in the BAC library. Thus 343 96-well plates would represent 9.4 genome equivalents. If each plate were a single pool it would take 343 PCRs to identify all plates containing a sequence of interest using appropriate primers (see Supplementary Tables 1 and $\mathbf{2}$ online). To reduce this to a manageable system, a 3D pooling strategy is described. This procedure works best if two people are working together.

An alternative to PCR screening is the arraying of BAC clones to nylon membrane such as Hybond NX membrane (Amersham). This method is less accurate than PCR screening and will not distinguish between homologous sequences. A number of robots are available, including the Beckman Biotech 2000 and the Qiagen Bio-Robot 3000, that can be custom programmed to array using a 96-pin replicating tool (VP scientific ${ }^{13}$ ) with the handle removed and the Genetix Q-Pix. A robot will array onto nylon membrane supported on LB chloramphenicol $\left(12.5 \mu \mathrm{g} \mathrm{ml}^{-1}\right)$ in a $120 \times 80-\mathrm{mm}^{2}$ omni tray or $220 \times 220-\mathrm{mm}^{2}$ plate. A range of spotting densities can usually be selected, but to make detection easier every clone should be arrayed in duplicate side by side. After arraying the $\mathrm{BAC}$ clones onto the membrane, the plates are incubated at $37{ }^{\circ} \mathrm{C}$ overnight and colony DNA transfer performed according to standard Southern blot procedures ${ }^{30,31}$.

Quality control (PCR screening of the library for chloroplast contamination). Primers (see MATERIALS and Table 1) were designed from wheat and barley sequences available in the public nucleotide databases and will work with a wide range of grass species. The primers should be tested on genomic DNA first and should amplify gene fragments of $1.4 \mathrm{~kb}(n d h A), 800 \mathrm{bp}(p s b A)$ and $1.2 \mathrm{~kb}(r b c L)$. An alternative to the PCR screen is to radiolabel the gene fragments and hybridize to nylon membranes of replicated BACs using a standard Southern analysis method ${ }^{30,31}$.

\section{MATERIALS}

\section{REAGENTS}

$\cdot 0.5 \times$ TBE $(\mathrm{BDH}$, Poole, UK)

$\cdot 10 \times$ Homogenization buffer (HB) (see REAGENT SETUP)

$\cdot 1 \times$ HEPES buffered saline (HBS) (see REAGENT SETUP)

- SOC medium

- Ethidium bromide

$\cdot 20 \%(\mathrm{v} / \mathrm{v})$ Triton X-100 in $1 \times$ HBS, store at $4{ }^{\circ} \mathrm{C}$

- Wash buffer (see REAGENT SETUP)

- Lysis buffer (see REAGENT SETUP)

- Tris-EDTA (TE) (10:1) and phenylmethylsulfonyl fluoride (PMSF) (see REAGENT SETUP)

- TE (20:50) (see REAGENT SETUP)

-TE (10:0.5) (see REAGENT SETUP)

- Low melting point (LMP) agarose (Sigma) (see REAGENT SETUP)

- LB agar (see REAGENT SETUP)

- Chloramphenicol $\left(12.5 \mu \mathrm{g} \mathrm{ml}^{-1}\right)$

- Isopropanol

- IPTG $\left(0.045 \% \mathrm{v} / \mathrm{v}\right.$ of $20 \% \mathrm{w} / \mathrm{v}$ stock in $\left.\mathrm{H}_{2} \mathrm{O}\right)$ (optional)

-X-gal $(0.45 \% \mathrm{v} / \mathrm{v}$ of $2 \% \mathrm{w} / \mathrm{v}$ stock in $\mathrm{NN}$-dimethyl formamide, optional)

- Preprepared vector such as pIndigoBAC5 (Epicentre, Madison, WI)

- High molecular weight (HMW) DNA ladder (lambda ladder PFG marker;

NEB, Beverly, MA)

-1-kb ladder (Hyperladder 1, Bioline, London, UK)

- Yeast tRNA (Ambion, Austin, TX)

- Buffer P1 (re-suspension buffer) (see REAGENT SETUP)

- Buffer P2 (lysis buffer) (see REAGENT SETUP)

- Buffer P3 (neutralization buffer) (see REAGENT SETUP)

$\cdot 5 \times$ Loading dye (see REAGENT SETUP)

- Freezing broth (see REAGENT SETUP)

- Primers for three chloroplast genes ( $n d h, p s b$ and $r b c L)$; see Table 1

- LB-agar chloramphenicol

\section{EQUIPMENT}

- Small paintbrush

-250-ml centrifuge bottles and suitable centrifuge set to $4{ }^{\circ} \mathrm{C}$

- 50-ml centrifuge tubes and suitable centrifuge set to $4{ }^{\circ} \mathrm{C}$

- Fixed angle rotor for 250-ml bottles

- Fixed angle rotor for 50 -ml bottles

- Swing-out 50-ml tube rotor

- Benchtop microfuge

- Waterbath

- Pre-chilled plug moulds (CHEF disposable plug moulds; BioRad,

Hercules, CA)

- Pre-chilled glass plate

-Wide-bore pipette tips $(200 \mu \mathrm{l}, 1,000 \mu \mathrm{l})$

- Pulsed-field gel electrophoresis (PFGE) apparatus (CHEF-DRII; BioRad,

Hercules, CA) (see EQUIPMENT SETUP)

-Wide Mini Sub Cell (BioRad, Hercules, CA)

- Dialysis tubing (Spectropore 2, Spectrum Medical Industries, Los Angeles,

CA) (see EQUIPMENT SETUP)

- Nitrocellulose filter (VS type $0.025-\mu \mathrm{m}$ nitrocellulose filter VSWP05000;

Millipore, Billerica, MA)

$\cdot 14{ }^{\circ} \mathrm{C}$ water bath

- Electroporater (Gene Pulser II apparatus; BioRad, Hercules, CA) (see EQUIPMENT SETUP)

$\cdot 22 \times 22-\mathrm{cm}^{2}$ square plates (Q trays; Genetix, Hampshire, UK)

- Glass balls, 2.5-3.5 mm (BDH, Poole, UK)

- Microtiter plate filler (QFill; Genetix, Hampshire, UK)

-Colony-picking robot (GloPix; Genetix, Hampshire, UK)

-96- or 384-well plates

- Multichannel pipette

-2-ml screw-top tubes

-5-ml pipette and pipette tips

- Arraying robot (BioRobot 3000; Qiagen, Crawley, UK) 
- Nunc OmniTrays (Sigma-Aldrich, St. Louis, MO)

- Nylon membrane (Hybond NX membrane; Amersham,

Buckinghamshire, UK)

REAGENT SETUP

10× HB stock $0.1 \mathrm{M}$ Trizma base, $0.8 \mathrm{M} \mathrm{KCl,} 0.1 \mathrm{M}$ EDTA, $10 \mathrm{mM}$ spermidine-HCl, $10 \mathrm{mM}$ spermine-HCl. $\mathrm{pH}$ to 9.4-9.5 with $\mathrm{NaOH}$. Store at $4{ }^{\circ} \mathrm{C}$. I CAUTION Spermidine- $\mathrm{HCl}$ and spermine- $\mathrm{HCl}$ are corrosive (cause burns), irritant and harmful. $\mathrm{NaOH}$ is corrosive (causes burns). $1 \times$ HBS $1 \times \mathrm{HB}$ stock, $0.5 \mathrm{M}$ sucrose. Store at $4{ }^{\circ} \mathrm{C}$.

Wash buffer $1 \times$ HBS, $0.5 \%(\mathrm{v} / \mathrm{v})$ Triton X-100 (from $20 \%(\mathrm{v} / \mathrm{v})$ stock), store at $4{ }^{\circ} \mathrm{C}$. Before use add $\beta$-mercaptoethanol to $0.15 \%(\mathrm{v} / \mathrm{v})$. ! CAUTION $\beta$-Mercaptoethanol is toxic by inhalation, ingestion and skin contact; severe eye irritant; causes burns; may be fatal by absorption through skin.

Lysis buffer 0.5 M EDTA ( $\mathrm{pH}$ 9.0-9.3), 1\% (w/v) sodium lauryl sarcosine. Before use add $0.1 \mathrm{mg} \mathrm{ml}^{-1}$ proteinase K. I CAUTION Proteinase K is an irritant; may cause allergic reactions.

TE (10:1) and PMSF $10 \mathrm{mM}$ Tris-HCl, $1 \mathrm{mM}$ EDTA pH 8.0, 0.1 mM PMSF. ! CAUTION Very toxic, severely corrosive. May be fatal if inhaled, absorbed through the skin or swallowed. Causes severe respiratory tract, digestive tract, eye and skin burns. Work in fume cupboard; wear protective clothing and gloves. Avoid all contact with skin and clothing. $\triangle$ CRITICAL PMSF has a short half-life in aqueous solutions. A stock solution should be made up in anhydrous isopropanol and stored at $4{ }^{\circ} \mathrm{C}$. Add to TE immediately before use.

TE (20:50) 20 mM Tris-HCl, 50 mM EDTA, pH 8.0.

TE (10:0.5) 10 mM Tris-HCl, 0.5 mM EDTA, pH 8.0 .

$1 \%$ LMP agarose $1 \%(\mathrm{w} / \mathrm{v})$ in $1 \times$ HBS. $\triangle$ CRITICAL Heat gently to melt to avoid caramelizing the sucrose in the HBS.

LB $10 \mathrm{~g}$ bactotryptone, $5 \mathrm{~g}$ bacto yeast extract, $10 \mathrm{~g} \mathrm{NaCl}$. Make up to $11 \mathrm{pH}$ to 7.0 with $\mathrm{NaOH}$.

LB-agar chloramphenicol $10 \mathrm{~g}$ bactotryptone, $5 \mathrm{~g}$ bacto yeast extract, $10 \mathrm{~g}$ $\mathrm{NaCl}$. Make up to $1 \mathrm{l} \mathrm{pH}$ to 7.0 with $\mathrm{NaOH}$. Add 1.5\% (w/v) agar before autoclaving. Make up in 300-ml batches. Before use add chloramphenicol to $12.5 \mu \mathrm{g} \mathrm{ml}^{-1}$, and for blue/white selection add IPTG (optional, 0.045\% v/v of $20 \% \mathrm{w} / \mathrm{v}$ stock in $\mathrm{H}_{2} \mathrm{O}$ ) and X-gal (optional, $0.45 \% \mathrm{v} / \mathrm{v}$ of $2 \% \mathrm{w} / \mathrm{v}$ stock in $N N$-dimethyl formamide). Plates should be poured in advance and dried for approximately $1 \mathrm{~h}$ in a sterile cabinet to reduce condensation. Before use remove prepared plates from cold and incubate at $37^{\circ} \mathrm{C}$ to avoid both condensation and shock to the cells. ! CAUTION NN-dimethyl formamide is a toxic, harmful irritant and teratogen (exposure may result in fetal death).

Buffer P1 (re-suspension buffer) $50 \mathrm{mM}$ Tris- $\mathrm{HCl}$ pH 8.0, 10 mM EDTA. Autoclave. Before use add $100 \mu \mathrm{g} \mu \mathrm{l}^{-1} \mathrm{RNaseA}$. Store at $4{ }^{\circ} \mathrm{C}$.

Buffer P2 (lysis buffer) $200 \mathrm{mM} \mathrm{NaOH}$. Autoclave. Before use add SDS to $1 \%(\mathrm{w} / \mathrm{v})$. Store at room temperature $\left(20-25^{\circ} \mathrm{C}\right)$.

Buffer P3 (neutralization buffer) $3 \mathrm{M}$ potassium acetate $\mathrm{pH}$ 5.5. Autoclave. Store at room temperature or $4{ }^{\circ} \mathrm{C}$. Chill to $4{ }^{\circ} \mathrm{C}$ before use.

$5 \times$ Loading dye $15 \mathrm{ml}$ glycerol, $2.5 \mathrm{ml} 0.5 \mathrm{M}$ EDTA pH 8.0, $125 \mathrm{mg}$

bromophenol blue. Make up to $50 \mathrm{ml}$ with sterile distilled water. Store at room temperature.

Freezing broth $29.5 \mathrm{~g}$ freezing broth (Formedium, Norwich, UK), $44 \mathrm{~g}$ glycerol. Make up to 11 with distilled water, pH 7.2 (with $\mathrm{NaOH}$ or $\mathrm{HCl}$ ); autoclave. Before use add chloramphenicol to $12.5 \mu \mathrm{g} \mathrm{ml}^{-1}$. I CAUTION NaOH and $\mathrm{HCl}$ are corrosive (cause burns).

EQUIPMENT SETUP

PFGE Before use, ensure PFGE tank is clean by rinsing with fresh $0.5 \times$ TBE. Pre-chill apparatus containing $0.5 \times$ TBE to $14^{\circ} \mathrm{C}$ and set the PFGE controller to $170 \mathrm{~V}$ for $16 \mathrm{~h}$ with a linear pulse ramp from 0.5 to $40 \mathrm{~s}$ using a PFGE apparatus such as the BioRad CHEF-DR II.

Note: For pre-electrophoresis, prepare a $1 \%(\mathrm{w} / \mathrm{v})$ agarose $0.5 \times \mathrm{TBE}$ ge using a comb modified to give a single long slot. Load 10-12 plugs into the slot and subject to PFGE using apparatus such as the BioRad CHEF-DR II. Pre-chill apparatus containing $0.5 \times$ TBE to $14{ }^{\circ} \mathrm{C}$ and set the PFGE controller to a 90 -s pulse time for $6 \mathrm{~h}$ at $150 \mathrm{~V}$ (ref. 32).

Preparation of dialysis tubing Tubing is prepared by heating strips of membrane $\left(12-15 \mathrm{~cm}\right.$ ) at $90^{\circ} \mathrm{C}$ in $1 \mathrm{mM}$ EDTA, $2 \% \mathrm{NaCO}_{3}$ for $10 \mathrm{~min}$, boiling in $\mathrm{H}_{2} \mathrm{O}$ for $10 \mathrm{~min}$ and rinsing several times in $\mathrm{H}_{2} \mathrm{O}$. Tubing may be stored after preparation in $50 \%(\mathrm{v} / \mathrm{v})$ ethanol at $4{ }^{\circ} \mathrm{C}$.

Transformation by electroporation Use an apparatus such as the Gene Pulser II apparatus (BioRad) set to $200 \omega, 25 \mu \mathrm{F}$ and $2.0 \mathrm{kV}$ (or settings recommended for large inserts by the supplier of the competent cells, which may vary).

\section{PROCEDURE}

\section{Isolation of nuclei for HMW DNA extraction TIMING $3 \mathbf{~ h}$}

1) Harvest $20 \mathrm{~g}$ of young leaves from glasshouse- or growthroom-grown Brachypodium plants that have been placed in the dark for $48 \mathrm{~h}$ to reduce carbohydrate concentration, which may cause carryover contamination and be detrimental to subsequent enzyme reactions. The leaves can be processed immediately or stored at $-80{ }^{\circ} \mathrm{C}$ for subsequent extraction. $\triangle$ CRITICAL STEP A standard genomic DNA extraction should be performed using material from the same plant to generate a control sample for use in screening the library by PCR. Each new set of primers must be tested on genomic DNA before library screening (see Step 90) and then used as a PCR control during screening to ensure both that the PCR conditions are suitable for amplification and that any observed band is of the expected size (see Step 92). The control genomic DNA should be of the same genotype as the library as polymorphisms between genotypes result in bands of different sizes being generated with some primer pairs.

PAUSE POINT Leaves can be stored at $-80{ }^{\circ} \mathrm{C}$ for up to 6 months.

2| Grind the leaf material to a fine powder in liquid nitrogen using a pestle and mortar.

3) Immediately transfer to an ice-cold $500-\mathrm{ml}$ beaker containing $200 \mathrm{ml}$ of ice-cold $1 \times$ wash buffer. Gently stir the contents with a magnetic stir bar for $10 \mathrm{~min}$ on ice.

4| Filter the mixture into an ice-cold 250-ml centrifuge bottle through three layers of miracloth in a funnel. Retrieve the remaining nuclei by squeezing the homogenate with clean-gloved hands.

5| Pellet the homogenate by centrifugation with a fixed-angle rotor at $1,800 \mathrm{~g}$ for 20 min at $4{ }^{\circ} \mathrm{C}$. Discard the supernatant.

6| Add $1 \mathrm{ml}$ of ice-cold wash buffer. Gently re-suspend the pellet using a small paint brush soaked in ice-cold wash buffer. Add $30 \mathrm{ml}$ ice-cold wash buffer.

7| Filter the re-suspended nuclei into a $50-\mathrm{ml}$ centrifuge tube through two layers of miracloth to remove particulate matter.

8| Centrifuge in a fixed-angle rotor at $57 \mathrm{~g}$ for $2 \mathrm{~min}$ at $4{ }^{\circ} \mathrm{C}$ to remove intact cell and tissue residues.

9| Transfer the supernatant into a clean $50-\mathrm{ml}$ tube and pellet the nuclei by centrifugation in a swing-out rotor at $1,800 \mathrm{~g}$ for 15 min at $4^{\circ} \mathrm{C}$. 
10| Wash the pellet twice by re-suspension in wash buffer followed by centrifugation at $1,800 \mathrm{~g}$ for 15 min at $4{ }^{\circ} \mathrm{C}$.

11 Re-suspend the pelleted nuclei in $1 \mathrm{~mL}$ of $1 \times$ HBS using a paint brush. Store on ice (for a maximum of $3 \mathrm{~h}$ ) and continue as soon as possible to the next step.

\section{Embedding nuclei in agarose plugs $\bigcirc$ TIMING $\mathbf{1} \mathbf{~ h}+$ overnight}

12| Prepare a $1 \%$ LMP agarose solution in $1 \times \mathrm{HBS}$ and incubate at $45^{\circ} \mathrm{C}$ in a waterbath.

13| Pre-warm the nuclei to $45{ }^{\circ} \mathrm{C}$ in a waterbath for 5-10 min. Mix the nuclei with an approximately equal volume (1 ml) of the $1 \%$ LMP agarose solution using a wide-bore pipette tip (prepared by slicing off the fine tip to produce a bore of $1.5-2 \mathrm{~mm}$ ).

14| Aliquot $95 \mu \mathrm{l}$ of the mixture into ice-cold CHEF disposable plug moulds on a level pre-chilled glass tray using a wide-bore pipette tip. A total of $20 \mathrm{~g}$ of leaf tissue should generate approximately 10-15 plugs.

PAUSE POINT Allow plugs to set fully overnight at $4{ }^{\circ} \mathrm{C}$.

\section{Lysis TIMING 24-48 h}

15| Transfer the plugs (take care as they may be fragile) into lysis buffer in a $50-\mathrm{ml}$ tube and incubate at $50{ }^{\circ} \mathrm{C}$ for $24-48 \mathrm{~h}$ with gentle shaking.

16| Wash the plugs in $0.5 \mathrm{M} \mathrm{EDTA}(\mathrm{pH} 9.0-9.3)$ for $1 \mathrm{~h}$ at $50{ }^{\circ} \mathrm{C}$ with shaking.

17| Wash the plugs in $0.05 \mathrm{M}$ EDTA (pH 8.0) for $1 \mathrm{~h}$ on ice with shaking.

$\triangle$ CRITICAL STEP Plugs should be washed a minimum of two times for $1 \mathrm{~h}$ in TE (20:50) with shaking to remove all traces of ethanol.

PAUSE POINT Store in $0.05 \mathrm{M}$ EDTA (pH 8.0) at $4{ }^{\circ} \mathrm{C}$. The plugs can be transported or shipped in $70 \%$ ethanol.

\section{Washing plugs $\bigcirc$ TIMING $7 \mathrm{~h}$}

18| Before use, wash the plugs containing the embedded nuclei ( $1 \mathrm{~h}$ per wash, on ice, with shaking) three times in 10-20 volumes of ice-cold TE (10:1) plus $0.1 \mathrm{mM}$ PMSF.

19| Wash three times (1 h per wash, on ice, with shaking) in 10-20 volumes of ice cold TE (20:50).

PAUSE POINT The washed plugs should be stored in TE (20:50) at $4{ }^{\circ} \mathrm{C}$ and are stable for several months without significant degradation of the DNA.

\section{Pre-electrophoresis $\bigcirc$ TIMING 7-8 h}

20| Before digestion, pre-electrophorese all agarose plugs containing nuclei as described in EQUIPMENT SETUP. Approximately 12 plugs will fit into the gel slot; this is the maximum number that can be pre-electrophoresed at one time.

$\triangle$ CRITICAL STEP Pre-electrophoresis improves restriction digestion and transformation efficiency 33,34 .

- PAUSE POINT After pre-electrophoresis, plugs should be stored in TE (20:50) at $4{ }^{\circ} \mathrm{C}$ and are stable for several months without significant degradation of the DNA.

\section{Test digests and size determination TIMING $8 \mathrm{~h}+$ overnight $+1 \mathrm{~h}$}

21| To determine the optimum quantity of restriction enzyme required for each batch of plugs, set up a series of eight test digests. To reduce the number of plugs used, cut four plugs in half. Incubate each pre-electrophoresed plug in $200 \mu \mathrm{l}$ of $1 \times$ restriction enzyme buffer $B$ (Roche) for $2 \times 1 \mathrm{~h}$ on ice (change buffer after $1 \mathrm{~h}$ ) to remove the TE buffer.

22 Incubate each half-plug in $200 \mu$ of restriction enzyme buffer containing BSA (100 mg ml-1) with 0, 0.1, 0.2, 0.5, 1, 2, 5 or $10 \mathrm{U}$ of HindIII (or BamHI) restriction enzyme in a microfuge tube for $4 \mathrm{~h}$ on ice so that the restriction enzyme mix can diffuse throughout the plugs.

23| Partially digest DNA by transferring the tubes containing the plugs to a water bath set at $37^{\circ} \mathrm{C}$. After exactly $1 \mathrm{~h}$ remove the tubes, add $1 \mathrm{ml}$ of $0.5 \times$ TBE buffer to stop the reaction and place on ice (for a maximum of $3 \mathrm{~h}$ ). Continue as soon as possible to the next step.

24| Load the plugs onto a $1 \%$ agarose $0.5 \times$ TBE gel, along with a solid matrix HMW DNA ladder, and separate the DNA in a single step by PFGE, as described in the EQUIPMENT SETUP.

25 Stain the gel in $1 \mu \mathrm{g} \mathrm{ml}^{-1}$ ethidium bromide in $0.5 \times$ TBE for 30 min with gentle shaking. Note: Ethidium bromide is an irritant and a strong mutagen, and may possibly be a carcinogen or teratogen. Ensure no splashing of ethidium bromide solution during the staining process. 
26 De-stain the gel in $0.5 \times$ TBE buffer for approximately 20 min with gentle shaking.

27| Place the gel on a UV transilluminator and photograph. Determine the optimal enzyme concentration as described in ANTICIPATED RESULTS. Figure 1 shows a typical test digest result.

\section{? TROUBLESHOOTING}

\section{Partial digestion and size selection of digested DNA TIMING $\mathbf{8} \mathbf{h}+$ overnight $+\mathbf{1} \mathbf{h}$}

28| In separate microfuge tubes incubate up to ten preelectrophoresed plugs in $400 \mu \mathrm{l} 1 \times$ restriction enzyme buffer B (Roche) for $2 \times 1 \mathrm{~h}$ on ice (change buffer after $1 \mathrm{~h}$ ).

29| Incubate plugs in $400 \mu \mathrm{l}$ of $1 \times$ restriction enzyme buffer containing $100 \mathrm{mg} \mathrm{ml}^{-1} \mathrm{BSA}$ with the appropriate amount of HindIII (or BamHI) restriction enzyme (as determined previously in the test digest at Step 27) in a microfuge tube for $4 \mathrm{~h}$ on ice.

$\triangle$ CRITICAL STEP Remember to double the number of units of enzyme for the whole plug with respect to the half-plug used in the test.

$\triangle$ CRITICAL STEP Make up enough $1 \times$ buffer, restriction enzyme and BSA for all the plugs in one tube and mix thoroughly before aliquoting to ensure all plugs receive the same treatment.

$\triangle$ CRITICAL STEP Prepare dialysis tubing at this stage, as detailed in the EQUIPMENT SETUP.

30| Perform partial digestions by transferring the tubes to a $37{ }^{\circ} \mathrm{C}$ water bath for $1 \mathrm{~h}$.

31 Stop the reaction by adding $1 \mathrm{ml} 0.5 \times$ TBE to each tube and then transfer them to ice.

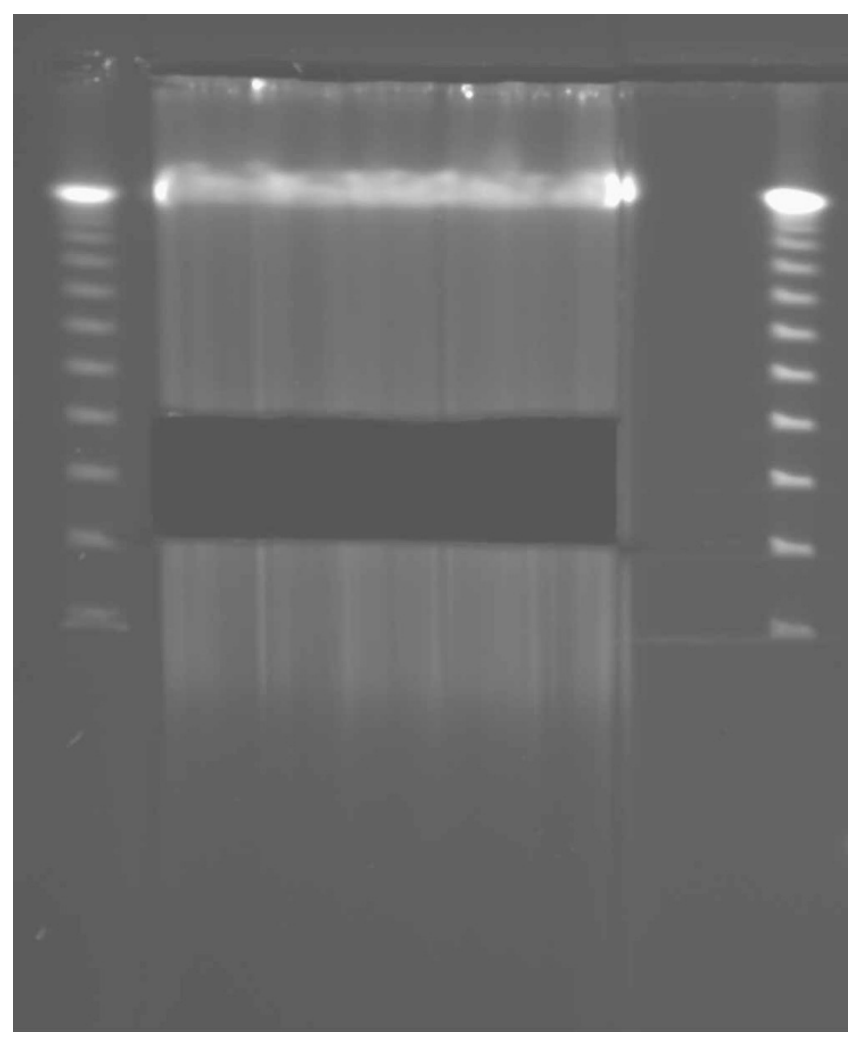

Figure 2 | Reconstructed gel after removal of gel slices containing target bacterial artificial chromosome (BAC) insert DNA after high molecular weight (HMW) DNA was subjected to a single pulsed-field gel electrophoresis (PFGE). The remaining gel pieces were stained with ethidium bromide before reconstruction to confirm restriction digestion occurred as predicted by trial digest. The left- and right-most lanes contain the HMW lambda ladder (NEB, Beverly, MA). The bottom three bands migrate at 145.5, 97.0 and $48.5 \mathrm{~kb}$.

32 Load plugs onto a $1 \%$ pulsed-field certified agarose $0.5 \times$ TBE gel with a single long slot as described in EQUIPMENT SETUP and add solid matrix HMW DNA markers at both ends of the slot as illustrated in Figure 2.

\section{3| Perform PFGE overnight as described in EQUIPMENT SETUP.}

34| After separation of the HMW DNA cut both flanking regions of the gel to include the DNA markers and approximately half of a plug and stain with ethidium bromide as described in Steps 25 and 26.

$\triangle$ CRITICAL STEP Cloning efficiency decreases with exposure to UV light. Do not expose the HMW DNA to be cloned to UV at any stage.

35 Under UV, use the DNA markers to mark the flanking regions with a clean scalpel blade at the lower boundary of the target size required (100 kb for inserts up to $100 \mathrm{~kb}, 150 \mathrm{~kb}$ for inserts up to $150 \mathrm{~kb}$, as described in EXPERIMENTAL DESIGN) and reassemble the gel on a clean glass plate, avoiding contact between the main part of the gel and the ethidium-stained flanking regions in order that the DNA for ligation remains ethidium bromide free.

36 Using the nicks in the flanking region as guides, cut the main gel to remove the smaller DNA fragments and set aside with the stained flanking regions. Make a second cut approximately $5 \mathrm{~mm}$ higher so that the gel fits snugly into the dialysis tubing in the next step (it is advisable to practice this step with an unwanted gel slice such as the set-aside piece containing the small fragments). More than one slice can be taken at this point to maximize the chance of obtaining a large number of inserts of the target size.

$\triangle$ CRITICAL STEP If consistently large inserts are required, the gel slice containing the desired DNA may be re-electrophoresed to remove small contaminating DNA fragments. PFGE should be performed as described in EQUIPMENT SETUP with the gel slot modified to accommodate the gel slice. Extreme care must be taken after re-electrophoresis of a gel slice to select exactly the same size region as that originally selected; otherwise much of the DNA will be lost. 
37| After removal of the gel slice(s) of interest into $0.5 \times$ TBE stain the remaining gel in ethidium bromide (as described in Steps 25 and 26) to confirm the restriction digest has proceeded as expected with respect to the test gel, as shown in Figures 2 and 3. This step is optional, but advisable-especially if a second electrophoresis step has been performed, to ensure the restriction digest has produced the expected result and that DNA has been recaptured. Proceed immediately to the next step.

\section{Electroelution and dialysis $\bigcirc$ TIMING $6 \mathbf{h}$}

38| Squeeze each agarose slice containing Brachypodium HMW DNA into prepared dialysis tubing. Seal one end with a clip and add $0.5 \times$ TBE to fill the tubing. Long slices may be divided into two for ease of manipulation, but this may result in less-concentrated DNA.

39| Ensure excess liquid and all air bubbles are removed and seal both ends securely. Removal of excess TBE is important to maximize DNA concentration.

40| Electroelute DNA from the agarose slice at $4{ }^{\circ} \mathrm{C}$ in $0.5 \times$ TBE for $3 \mathrm{~h}$ at $75 \mathrm{~V}$ in an ethidium bromide-free electrophoresis tank. Ensure tubing is fully submerged and weigh down gently if necessary. Electroelution is performed as described by Strong et al. $^{35}$

$\triangle$ CRITICAL STEP It is advisable to pour LB agar-chloramphenicol plates at this point.

41 After electroelution, reverse the polarity of the electrodes for $30 \mathrm{~s}$ to move DNA away from the dialysis tubing.

$\triangle$ CRITICAL STEP Prepare the drop dialysis setup in advance so that electroeluted DNA can be removed from the dialysis tubing directly onto the nitrocellulose filter with no delay.

42 Remove the clip from one end of the tubing and extract the gel slice from the tubing, taking care not to spill the buffer, which contains the HMW DNA.

43| Remove the buffer with a wide-bore pipette tip. The volume recovered will depend on the size of the gel slice taken but should be in the region of 100-300 $\mu \mathrm{l}$ for a 10-plug gel slice. Larger volumes will have relatively less-concentrated DNA than smaller volumes from the same gel slice. Up to $30 \%$ of this volume (relatively less for larger volumes) may be lost on the dialysis filter during the subsequent dialysis. Drop-dialyze the DNA by placing the buffer containing the HMW DNA directly onto a nitrocellulose filter, suspended (shiny side up) on $25 \mathrm{ml}$ ice-cold TE (10:0.5) for $2 \times 1 \mathrm{~h}$ in a 90-mm Petri dish suspended on ice. Continue immediately to the next step.

\section{? TROUBLESHOOTING}

\section{Ligation TIMING $\mathbf{1 . 5} \mathbf{h}$ + overnight}

44| Load $20 \mu \mathrm{l}$ of the dialysed DNA and an aliquot of a weighted DNA marker, such as Hyperladder I (Bioline), onto a $1 \%$ agarose gel and electrophorese using standard conditions such as $100 \mathrm{~V}$ for a mini-gel for $30 \mathrm{~min}$. Ethidium bromide can be included in the agarose gel or it can be subsequently stained and de-stained as described above (Steps 25 and 26).

45| Transfer the gel onto a UV transilluminator and photograph. Determine the approximate DNA concentration by comparison to the DNA markers.

46| Prepare a $100-\mu$ l ligation reaction as detailed in the following table. Ligate at $14{ }^{\circ} \mathrm{C}$ overnight.

\begin{tabular}{lcl}
\hline Component & Amount per reaction $(\mu \mathrm{l})$ & Final \\
\hline Partially digested HMW DNA (from Step 43) & 85 & Approximately $5 \mathrm{ng}$ \\
Linear BAC vector $\left(25{\mathrm{ng} \mathrm{l}^{-1}}^{-1}\right.$ & 3 & $75 \mathrm{ng}$ \\
T4 DNA ligase buffer $(10 \times)$ & 10 & $1 \times$ \\
T4 DNA ligase $\left(1 \cup \mu \mathrm{l}^{-1}\right)$ & 2 & 2 Weiss units \\
\hline
\end{tabular}

$\triangle$ CRITICAL STEP The aim should be to achieve a ratio of one molecule of vector to ten molecules of HMW DNA on the basis of the average insert size predicted from the DNA sizes excised in the gel slice. For the purpose of calculations, assume that a single size 
PROTOCOL

selection as described previously will generate BACs with an average insert size of $100 \mathrm{~kb}$ and a double size selection will generate BACs with an average insert size of $125 \mathrm{~kb}$.

\section{Transformation $\bigcirc$ TIMING 4-5 h (day 4) +16 h (overnight)}

47| Immediately after overnight ligation, drop dialyze the ligation reaction for $2 \times 1 \mathrm{~h}$ as described in Step 43 using a Millipore filter suspended on ice-cold TE (10:0.5).

48| Using a wide-bore pipette tip, pipette $20 \mu \mathrm{l}$ of the ligation product into $100 \mu \mathrm{l}$ of electrocompetent cells, on ice. Add $4 \mu \mathrm{l}$ of yeast tRNA at $1.25 \mathrm{mg} \mathrm{ml}^{-1}$ to increase the transformation efficiency ${ }^{36}$.

$\triangle$ CRITICAL STEP Read information supplied with competent cells before use. Cells should be thawed gently on ice and both cuvettes and the cuvette holder should be pre-chilled to $-20{ }^{\circ} \mathrm{C}$ before use.

49| Gently mix and (using a wide-bore pipette tip) pipette $30 \mu \mathrm{l}$ of the mixture into a pre-chilled 1-mm electroporation cuvette and electroporate (see EQUIPMENT SETUP).

50| After electroporation, immediately add 500-1,000 $\mu$ of room-temperature SOC medium (supplied with cells). Do not return cells to ice; stand at room temperature.

51| Once all cells are electroporated, remove into microfuge tubes and incubate at $37^{\circ} \mathrm{C}$ with vigorous shaking (200 r.p.m.).

52| After 45 min pipette the cells onto room-temperature, or slightly warm, LB-agar containing $12.5 \mu \mathrm{g} \mathrm{m}^{-1}$ of chloramphenicol in $220 \times 220-\mathrm{mm}^{2}$ plates as described in REAGENT SETUP (the addition of IPTG and Xgal for blue/white selection is optional). Spread the cells using autoclaved glass balls by shaking the beads across the plate.

53 Incubate the plates at $37^{\circ} \mathrm{C}$ for approximately $16 \mathrm{~h}$.

PAUSE POINT After overnight incubation, the plates should be sealed with parafilm and may be stored for up to 4 weeks in a cold room or fridge.

? TROUBLESHOOTING

Initial assessment of BAC library insert size TIMING $1 \mathrm{~h}+$ overnight, $4.5 \mathrm{~h}+$ overnight, $1 \mathrm{~h}$

54| Select 12-24 BACs sampled from several plates and, for each BAC, inoculate $2 \mathrm{~mL}$ of LB containing chloramphenicol at a concentration of $12.5 \mu \mathrm{g} \mathrm{ml}^{-1}$. Incubate the 2 -ml cultures on a shaking platform at $37^{\circ} \mathrm{C}$ overnight.

55| Transfer the culture to a 2-ml microfuge tube and centrifuge at 6,000 $\mathrm{g}$ for $5 \mathrm{~min}$. Remove the clear supernatant (autoclave to dispose).

- PAUSE POINT Bacterial pellets may be frozen at $-20{ }^{\circ} \mathrm{C}$ for several weeks.

56| Re-suspend the pellet in $300 \mu$ ice-cold P1 buffer.

57| Add $300 \mu \mathrm{l} \mathrm{P2} \mathrm{buffer,} \mathrm{invert} \mathrm{tube} \mathrm{to} \mathrm{mix} \mathrm{and} \mathrm{incubate} \mathrm{(no} \mathrm{longer} \mathrm{than)} 5 \mathrm{~min}$ at room temperature.

58| Add $300 \mu$ ice-cold N3 buffer, invert tube to mix and incubate on ice $10 \mathrm{~min}$.

59| Centrifuge at $12,000 \mathrm{~g}$ for $10 \mathrm{~min}$.

60| Transfer supernatant to a fresh $1.5-\mathrm{ml}$ tube and centrifuge again at $12,000 \mathrm{~g}$ for $10 \mathrm{~min}$.

61| Transfer supernatant to a fresh tube with $650 \mu \mathrm{l}$ isopropanol, invert to mix and incubate at room temperature for 2 min.

62| Centrifuge at $14,000 \mathrm{~g}$ for $20 \mathrm{~min}$.

63 Remove the supernatant and wash the pellet with $70 \%$ ethanol. Incubate at room temperature for 2 min, centrifuge at $14,000 \mathrm{~g}$ for $2 \mathrm{~min}$ and remove the supernatant.

64 Allow the pellet to dry at room temperature and re-suspend in $40 \mu \mathrm{l} 0.5 \times$ TE buffer ( $5 \mathrm{mM}$ Tris-HCl, $0.5 \mathrm{mM}$ EDTA, pH 8.0). - PAUSE POINT BAC preps may be stored at $-20^{\circ} \mathrm{C}$ for several months.

65 Prepare a 20- $\mu$ l restriction digest reaction for each BAC DNA preparation comprising $10 \mu \mathrm{LNA}, 2 \mu \mathrm{l} 10 \times$ buffer and $5 \mathrm{U}$ of NotI (assuming the use of a pBeloBAC11-derived vector such as pIndigoBAC5). Incubate at $37{ }^{\circ} \mathrm{C}$ for a minimum of $2 \mathrm{~h}$.

66 Add $4 \mu$ l of $5 \times$ loading dye and load the samples on a $1 \%(w / v)$ agarose gel along with HMW and $1 \mathrm{~kb}$ ladders. Size-separate using PFGE, setting the controller to $170 \mathrm{~V}$ for $16 \mathrm{~h}$ with a linear pulse ramp from 0.5 to $40 \mathrm{~s}$. 
Figure 4 | DNA from randomly selected bacterial artificial chromosome (BAC) clones was restricted using NotI and fragments separated by pulsed-field gel electrophoresis (PFGE). The average sizes of the BAC inserts in this figure are estimated as approximately $125 \mathrm{~kb}$. The arrowheads to the left indicate (from top to bottom) the 145.5, 97.0 and $48.5 \mathrm{~kb}$ bands of the lambda ladder (NEB, Beverly, MA), the $12.2 \mathrm{~kb}$ band of the DNA Molecular Weight Marker X (Roche) and the position of the pIndigoBAC5 NotI vector fragment. This figure is reproduced with permission from ref. 12

67| Stain the gel with ethidium bromide, place on a UV transilluminator and photograph as detailed in Steps 25 and 26 and illustrated in Figure 4. Using the high and low molecular weight DNA standards, estimate the sizes of the DNA fragments in each lane excluding the common vector band. Ensure any bands migrating close to each other are not excluded.

? TROUBLESHOOTING

68| Assuming the majority of clones contain inserts and the range and average insert size is adequate to proceed, pick more $\mathrm{BAC}$ clones with which to repeat the procedure. Measure the insert size of at least 48 clones to determine the average insert size.

\section{Test for chloroplast contamination $\bigcirc$ TIMING 1 d}

69| To test for chloroplast contamination of the BAC library, set up a PCR using primers for the three chloroplast genes listed in Table 1, as detailed in the following table. The three primer pairs may be added to a single reaction containing $1 \mu$ of BAC DNA from $4 \times 96$-well plates (adjust the volume of water to compensate for additional primer pairs).

\begin{tabular}{lcl}
\hline Component & Amount per reaction $(\mu \mathrm{l})$ & Final \\
\hline DNA & 1 & \\
$10 \times$ buffer & 2 & $1 \times$ \\
dNTPs $(10 \mathrm{mM})$ & 0.5 & $0.25 \mathrm{mM}$ \\
Primer $1(10 \mu \mathrm{M})$ & 1 & $0.5 \mu \mathrm{M}$ \\
Primer $2(10 \mu \mathrm{M})$ & 1 & $0.5 \mu \mathrm{M}$ \\
Taq $\left(5 \mathrm{U} \mu \mathrm{l}^{-1}\right)$ & 0.2 & $1 \mathrm{U}$ \\
$\mathrm{H}_{2} \mathrm{O}$ & 14.3 & Adjust as necessary to make final volume of $20 \mu \mathrm{l}$ \\
\hline
\end{tabular}

70| Perform PCR as detailed in the following table.

\begin{tabular}{llll}
\hline Step & Denature & Anneal & Extend \\
\hline 1 & $94^{\circ} \mathrm{C}, 5 \mathrm{~min}$ & & \\
$2-36$ & $94^{\circ} \mathrm{C}, 30 \mathrm{~s}$ & $57{ }^{\circ} \mathrm{C}, 30 \mathrm{~s}$ & $72{ }^{\circ} \mathrm{C} 1 \mathrm{~min} \mathrm{~kb}$ \\
37 & & & $72{ }^{\circ} \mathrm{C} 10 \mathrm{~min}$ \\
\hline
\end{tabular}

PAUSE POINT The reaction can be stored at $4{ }^{\circ} \mathrm{C}$ for up to $72 \mathrm{~h}$, if required. ? TROUBLESHOOTING

\section{Picking TIMING Several days, depending on the number of colonies generated/required}

71| Remove the plates (from Step 53) from $4{ }^{\circ} \mathrm{C}$ and incubate at $37^{\circ} \mathrm{C}$, agar side up, to prevent condensation, which can cause contamination.

72 Pick colonies either by hand or using a colony-picking robot such as the QPix II or GloPix (Genetix). See Box 1 for tips on picking colonies.

73| Incubate the plates at $37{ }^{\circ} \mathrm{C}$ for $24 \mathrm{~h}$ without shaking.

PAUSE POINT Plates can be stored at $-80^{\circ} \mathrm{C}$ indefinitely.

\section{Screening the library by PCR $\bigcirc$ TIMING More than 3 weeks}

74| Replicate the entire library into 343 new 96-well microtiter plates, with each well containing $200 \mu \mathrm{L}$ of LB and chloramphenicol at a concentration of $12.5 \mu \mathrm{g} \mathrm{ml}^{-1}$. Fill plates with an automated system (e.g., the Qfill, Genetix) or using a multi-channel pipette.

75| Incubate the plates at $37^{\circ} \mathrm{C}$ overnight. 


\section{BOX 1 | TIPS ON PICKING COLONIES}

\section{Handpicking}

1. Use cocktail sticks and work from the left of a plate (if you are right-handed) and progress across, starting at the back and working forward.

2. Use double-ended cocktail sticks, which enable two colonies to be picked.

3. Leave the sticks in situ in alternate wells until an entire plate is picked to be sure which wells are inoculated.

4. Pick into 96-well plates containing $200 \mu \mathrm{l}$ per well of freezing broth and chloramphenicol as described in REAGENTS.

5. Make a copy as a backup, which should be stored in a different freezer. It is best to use a 96-pin replicating tool once the first plate has grown. Robot picking

1. Follow the manufacturer's instructions and pick into 96 -well plates containing $200 \mu \mathrm{l}$ of freezing broth and $12.5 \mu \mathrm{g} \mathrm{ml} \mathrm{L}^{-1}$ of chloramphenicol (384-well plates may be preferred).

2. Make a copy as a backup, which should be stored in a different freezer. Robots can usually be programmed to pick multiple copies during the picking stage.

76| For each plate, pool the cultures from all 96-wells into a 50-ml plastic centrifuge tube (Greiner) using a multi-channel pipette to pipette the entire contents of each well into the lid before pouring into the tube to ensure no cultures are lost or under-represented.

77| Arrange the 343 'plate' pools into superpools in 3D $(X, Y$, $Z$ ), with $6 \mathrm{ml}$ of culture from each of seven plates $(=672$ clones in $42 \mathrm{~mL}$ of LB) in each of 147 superpools (see Fig. 5 and Supplementary Tables 1 and 2). This means that each plate will be represented in three different pools so that, once DNA has been extracted, a PCR screen of 147 DNA pools should generate three positive bands per colony, two to identify the specific plate and the third as confirmation. In practice two dimensions (i.e., 98 PCRs) should be sufficient to identify a plate containing a PCR-postive BAC.

78| Centrifuge the 50-ml plastic tubes containing the superpooled cultures at $6,000 \mathrm{~g}$ in a bench-top centrifuge such as the Eppendorf 5403. The supernatants are discarded (autoclave before disposal) and the pellets used for DNA extraction.

PAUSE POINT Pellets can be stored at $-80^{\circ} \mathrm{C}$ for up to 3 months at $-20^{\circ} \mathrm{C}$.

79| Isolate BAC DNA from the pellets using an alkaline-lysis plasmid-DNA extraction method including RNase treatment as described in Steps 80-89 below.

80| Re-suspend the pellet in $4 \mathrm{ml}$ of $\mathrm{P} 1$ buffer (containing RNase) and transfer to an autoclaved 50-ml tube.

81| Add $4 \mathrm{ml}$ of P2 buffer, mix gently and leave for not more than 5 min at room temperature.

Figure 5 | Representation of the 3D pooling strategy for PCR screening of the bacterial artificial chromosome (BAC) library. BAC clones from 343 plates are replicated into new 96 -well plates containing LB medium and $12.5 \mu \mathrm{g} \mathrm{ml}^{-1}$ chloramphenicol and grown overnight. The overnight cultures of the $96 \mathrm{BACs}$ within each plate are pooled to make 343 plate pools. The 343 plate pools are arranged in a virtual $7 \times 7 \times 7$ cube so that each plate can be pooled in each of three dimensions $(X, Y, Z)$ with seven plates in each superpool. The colored squares show that plate 7 is a member of three superpools: in the $X$ dimension with plates 1, 2, 3, 4, 5 and 6 ; in the $Y$ dimension with plates $14,21,28,35$, 42 and 49; and in the $Z$ dimension with plates 56, 105, 154, 203, 252, 301. Two dimensions (98 PCRs) will identify an individual plate and the third dimension (a further 49 PCRs) will confirm this. Supplementary Table 1 lists which three superpools an individual plate pool should be represented in, and Supplementary Table 2 lists which seven plates are combined in each superpool.

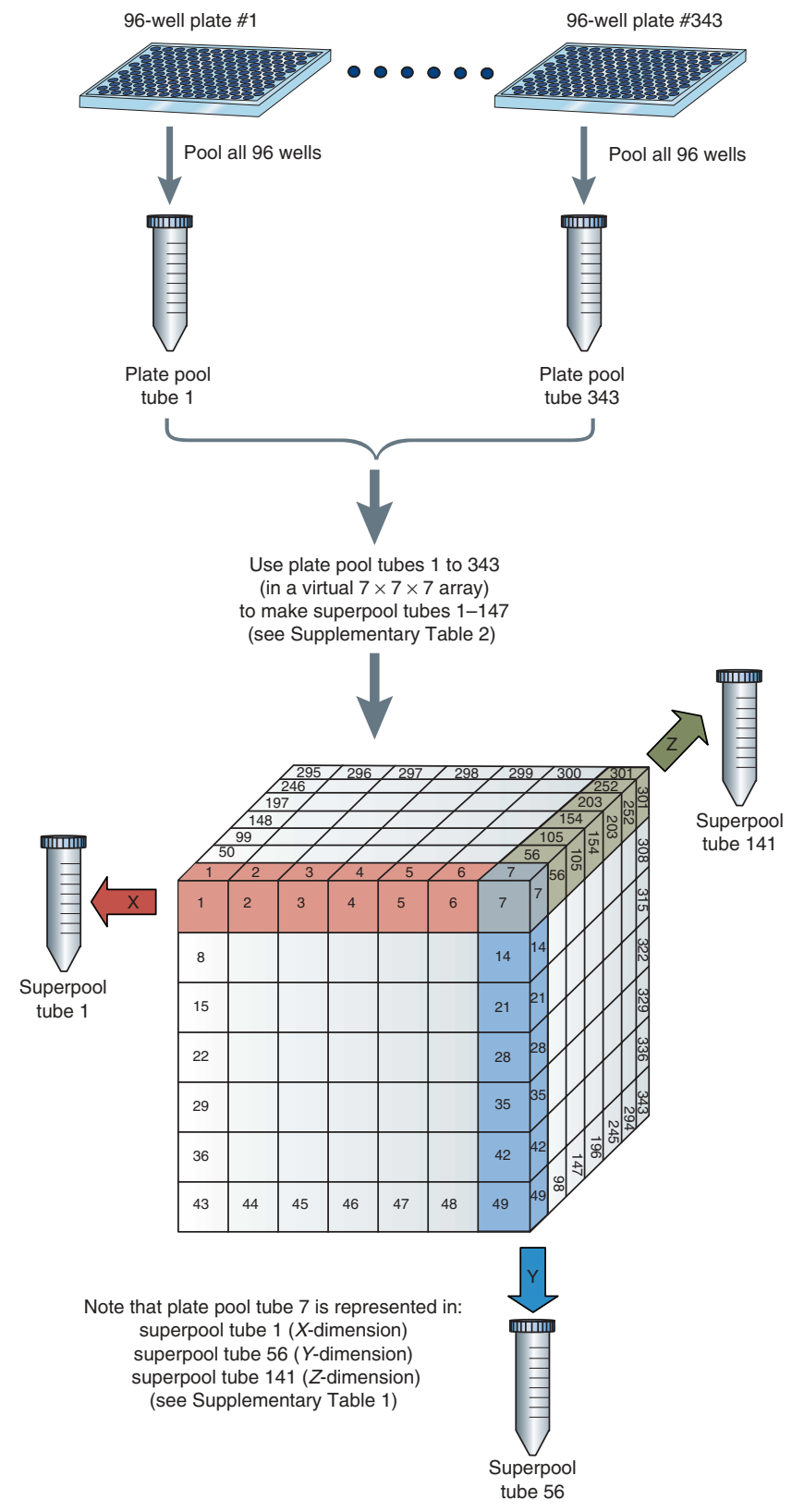


82 Add $4 \mathrm{ml}$ of chilled P3 buffer, mix and leave on ice for $15 \mathrm{~min}$.

83| Centrifuge at $4{ }^{\circ} \mathrm{C}$ for $25 \mathrm{~min}$ at $14,000 \mathrm{~g}$ (e.g., using a $24 \mathrm{M}$ centrifuge, $8 \times 50$ rotor).

84| Transfer the supernatant to a fresh $50-\mathrm{ml}$ tube and re-centrifuge for $15 \mathrm{~min}$.

85 Add the supernatant to $8 \mathrm{ml}$ of isopropanol; leave to stand for $10 \mathrm{~min}$ at room temperature.

86| Centrifuge at $4{ }^{\circ} \mathrm{C}$ for $25 \mathrm{~min}$ at $14,000 \mathrm{~g}$.

87| To wash the pellet, add $1.5 \mathrm{ml}$ of $70 \%(\mathrm{v} / \mathrm{v})$ ethanol and transfer to a 2-ml tube using a wide-bore pipette tip. Centrifuge at $4^{\circ} \mathrm{C}$ for $10 \mathrm{~min}$ at $14,000 \mathrm{~g}$.

88| Pour off the supernatant and repeat Step 86 with $1 \mathrm{ml}$ $70 \%(\mathrm{v} / \mathrm{v})$ ethanol.

89| Air-dry and re-suspend the pellet in $200 \mu \mathrm{l} 0.5 \times$ TE.

PAUSE POINT Store at $-20{ }^{\circ} \mathrm{C}$.

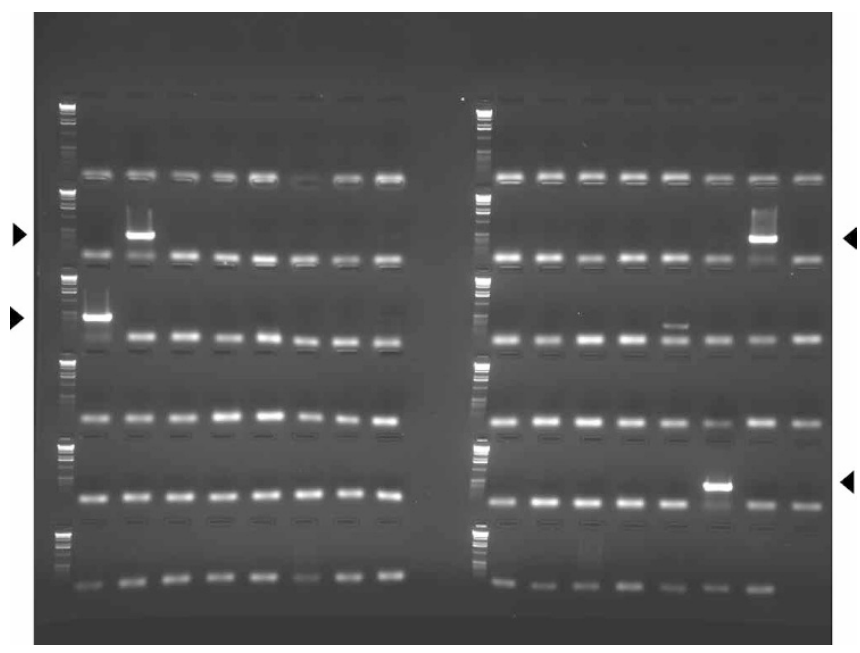

Figure 6 | PCR-based screen of BAC DNA pools using gene specific primers. PCR products of the correct size were identified in pools $10,17,63,86$ (as indicated by arrow heads). The left-hand lanes contain the DNA Molecular Weight Marker X (Roche).

90| Test all primers used to screen the BAC library on Brachypodium genomic DNA of the same genotype used to generate the library. PCR components and conditions are described in Steps 69 and 70 respectively and should be optimized using genomic DNA before being used to screen the BAC library ${ }^{31}$. After a successful PCR, run the sample on an agarose gel, excise any PCR fragment and sequence to ensure it is the expected sequence.

\section{? TROUBLESHOOTING}

91 Perform a primary PCR screen using the optimied conditions determined in Step 90: screen the three dimensions of the BAC library (147 superpools). Two dimensions (98 PCRs) will identify an individual plate and the third dimension (a further 49 PCRs) will confirm this. Superpool DNA is stored in 96-well plates and $1 \mu \mathrm{l}$ of a 1-in-10 dilution is used in a 20- $\mu$ PCR as detailed in Step 69.

92 Run the PCRs on a $1 \%(\mathrm{w} / \mathrm{v})$ agarose $0.5 \times$ TBE gel. In some cases there may be bands of more than one size; should this occur repeat the PCR using an appropriate number of genomic controls (one per row on the diagnostic agarose gel) to be sure that any observed band is of the correct size. See Figure 6 for the result of a PCR screen using a single pair of primers.

? TROUBLESHOOTING

93 Identify pools in which a PCR-positive band of the correct size is present for the specific primers. Use a matrix (see Supplementary Tables 1 and 2) to check which plates made up the pool and therefore which plate(s) contain a PCR-positive BAC.

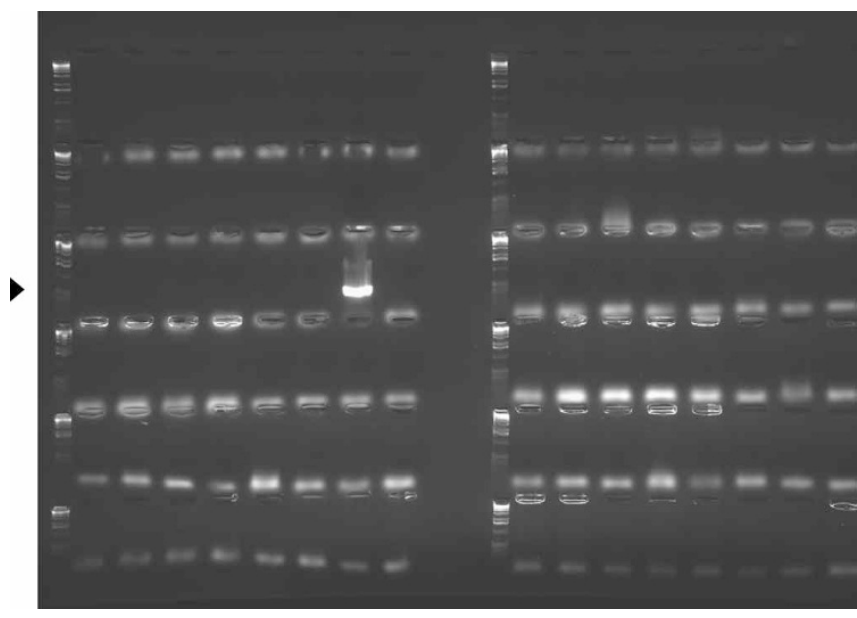

Figure 7 | PCR-based screen of individual BACs using gene-specific primers. A PCR product of the correct size was identified in well 23 (as indicated by arrow head). The left-hand lanes contain the DNA Molecular Weight Marker X (Roche).
94| Perform a secondary PCR screen to identify the individual BAC from the 96-well plate. Inoculate another plate containing $200 \mu \mathrm{LB}$ and chloramphenicol $\left(12.5 \mu \mathrm{g} \mathrm{m}^{-1}\right)$ and grow at $37^{\circ} \mathrm{C}$ overnight.

95| Perform colony PCR using $1 \mu$ l of cells directly from the plate as DNA template and screen by PCR using the volumes and conditions described in Step 91. See Figure 7 for an example of results.

96| Once an individual BAC clone has been identified, grow an overnight culture and extract DNA as described in Steps 55-64.

97| Perform the PCR using the appropriate specific primers, as described in Step 91, and, if confirmed as positive, directly sequence the BAC using the same primers.

\section{TIMING}

Make up solutions in advance

Week 1, day 1: generate HMW nuclei and embed in agarose plugs, $3 \mathrm{~h}+1 \mathrm{~h}+$ overnight 
PROTOCOL

Week 1, day 2: lyse nuclei, 24-48 $\mathrm{h}+2 \mathrm{~h}$

Week 1, day 4: washes, $7 \mathrm{~h}$

Week 1, day 5: pre-electrophoresis, $8 \mathrm{~h}$

Week 2, day 1: test digests, $8 \mathrm{~h}+$ overnight

Week 2, day 2: check gel and determine optimum restriction enzyme concentration, $1 \mathrm{~h}$, digest

DNA $8 \mathrm{~h}+$ overnight

Week 2, day 3: size selection, electroelute HMW DNA, dialysis, ligate, $8 \mathrm{~h}+$ overnight

Week 2, day 4: dialyze ligation, transformation, grow cells, $5 \mathrm{~h}+$ overnight

Week 2, day 5: transfer plates to $4{ }^{\circ} \mathrm{C}$

Weeks 3 and 4, day 1: pick colonies and incubate cultures, $1 \mathrm{~h}+$ overnight

Weeks 3 and 4, day 2: BAC preps and digests, $5 \mathrm{~h}+$ electrophorese overnight

Weeks 3 and 4, day 3: check gel $1 \mathrm{~h}$, PCR to test for chloroplast contamination, $4 \mathrm{~h}$

Weeks 3 and 4, day 4 onward: picking colonies

Weeks 5 and 6: generating and BAC preps of superpools

Week 7 onward: screening the library

\section{? TROUBLESHOOTING}

Troubleshooting advice can be found in Table 2 .

TABLE 2 | Troubleshooting table.

\begin{tabular}{llll}
\hline Step & Problem & Possible reason & Solution \\
\hline 27 & $\begin{array}{l}\text { HMW DNA does not restrict or } \\
\text { appears degraded after the } 0 \mathrm{U} \\
\text { enzyme treatment }\end{array}$ & DNA not pure enough & $\begin{array}{l}\text { Re-perform extraction and washing steps, ensuring all } \\
\text { solutions are fresh and correct }\end{array}$ \\
& DNA concentration too low & Low DNA yields & $\begin{array}{l}\text { Repeat using more plugs or extract DNA from younger } \\
\text { tissue }\end{array}$ \\
& DNA lost during dialysis steps & $\begin{array}{l}\text { Place gel slice tightly in dialysis tubing, eliminate excess } \\
\text { buffer and place clips close to the gel slice. Take care not } \\
\text { to lose the buffer containing the HMW DNA when } \\
\end{array}$ \\
& & removing the gel slice \\
& DNA lost after second & Ensure that the DNA is efficiently recovered
\end{tabular}

No or too few BAC clones

BAC clones too small

67

$70,90 \quad$ No bands on gel electrophoresis step

Cells not competent Electroporation failed

Electroporation inefficient DNA concentration too low

Shearing of HMW DNA

Too long taken between performing steps

Contamination from small fragments

Inaccurate excision of gel slice

Component of PCR mix missing

Insufficient cycles

Annealing temperature too high

Magnesium concentration not optimized
Buy new electrocompetent cells

Check whether cells are electrocompetent and in correct buffer

Ensure correct settings for large plasmids are utilized Ensure all excess liquid is removed from the dialysis tubing before eletroelution

Ensure wide-bore pipette tips are used wherever HMW DNA is to be pipetted and keep all pipetting to a minimum

Pause only at Pause Points indicated. Start procedure and perform on consecutive days

Use less restriction enzyme or a lower concentration of DNA, or perform second electrophoresis step Re-perform restriction and size separation

Re-perform PCR ensuring all components are fresh Re-perform PCR increasing the number of cycles in Step 2 Perform gradient PCR to obtain optimum annealing temperature, or repeat PCR with lower annealing temperature

Re-perform PCR ensuring buffer is fresh and well vortexed, or use buffer without magnesium and add magnesium at different concentrations to establish optimum 
TABLE 2 | Troubleshooting table (continued).

\begin{tabular}{llll}
\hline Step & Problem & Possible reason & Solution \\
\hline & $\begin{array}{l}\text { Too many bands on gel; bands } \\
\text { of wrong size on gel }\end{array}$ & Annealing temperature too low & $\begin{array}{l}\text { Perform gradient PCR to obtain optimum annealing } \\
\text { temperature, or repeat PCR with higher annealing } \\
\text { temperature }\end{array}$ \\
$92 \quad \begin{array}{l}\text { Too many BAC clones identified } \\
\text { in PCR screen }\end{array}$ & Primers not specific enough & Design new primers \\
\hline
\end{tabular}

\section{ANTICIPATED RESULTS}

The protocol described here routinely results in the production of BAC libraries with moderate to large (90-150 kb) inserts, good genome coverage and a low background of contamination with organelle DNA. With this protocol it should be possible to isolate HMW Brachypodium DNA, generate a BAC library and set up pools of BAC DNA that can be screened by conventional PCR methods to identify a BAC pool and then a single BAC that contains a target DNA sequence such as a gene or marker of interest.

The effectiveness of the HMW DNA isolation and DNA quality are determined by the test digests. The DNA should be visibly more digested with each increase in restriction enzyme concentration (e.g., see Fig. 1), and ideally only 0.2-0.5 $\mathrm{U}$ of enzyme should be necessary to digest the DNA in a Brachypodium DNA plug sufficiently to create a smear of DNA in the 100-150 kb region of the gel. Once DNA that will restrict has been isolated, the next step is to scale up the restriction digest to ten plugs with a single enzyme concentration. The effectiveness of this step can be verified after the gel slices spanning the target size range have been excised as the remainder of the gel can be stained to confirm that the scaled-up digest was comparable to that predicted by the test digest (Fig. 2). The excised DNA is extracted from the gel slice by dialysis, and the effectiveness of the recovery is determined by loading a sample on an agarose gel; this step is also necessary to determine the DNA concentration for the ligation reaction. After ligation overnight, the DNA is dialyzed and electroporated into competent $E$. coli cells. The cells are plated onto LB medium containing chloramphenicol and incubated at $37^{\circ} \mathrm{C}$ overnight, and a high density $(100 \mathrm{~s}-1,000 \mathrm{~s})$ of colonies on these plates is a good indicator of the success of the entire BAC library procedure. For example, artifacts are seldom seen when large numbers of clones are produced; however, empty vector and small clones can become frequent when the efficiency and the total number of clones per plate achieved are low.

In a BAC library, it is desirable to ensure that the maximum number of sequences are represented. The likelihood of finding a specific DNA or gene sequence in the library is most easily improved by increasing the genome coverage. For example, the probability $(P)$ of any given gene being represented is theoretically $P=1-\mathrm{e}^{N[\ln (1-I / G S)]}$, where $N$ is the number of BAC clones in the library; $I$ is the average insert size of the clones in the BAC library; and GS is the haploid genome size ${ }^{37}$, which is $355 \mathrm{Mb}$ for $B$. distachyon ${ }^{29}$. Using this equation it is possible to calculate that $16,350 \mathrm{BAC}$ clones of $100 \mathrm{~kb}$ would be necessary to give a $99 \%$ chance of finding a specific DNA sequence. However, this is only a theoretical estimate, and in reality to achieve such a high frequency of success across the entire genome it would be necessary to make multiple BAC libraries using different restriction enzymes, and even then there still may be problems because of complications or toxicity in the bacterial host.

The average insert size of BAC clones is determined by selecting BACs for overnight culture in liquid LB and plasmid DNA preparation. The BAC DNA is restriction digested using NotI and the product electrophoresed alongside high and low molecular weight DNA size markers (Fig. 4). The size of the individual BAC insert fragments is calculated, from a photograph or electronic image, relative to the DNA size markers. Once a BAC library has been produced with the required number of clones, PCR-based screening can be set up by growing all the BAC clones up in a new replicate set of microtiter plates. Overnight cultures of BAC clones are pooled in groups of seven plates in a 3D structure (Fig. 5; Supplementary Tables 1 and 2) and BAC DNA is isolated. When the cultures are screened with PCR primers for candidate genes or markers, BAC pools and individual BACs can be identified (Figs. 6, 7) and verified by DNA sequencing. By using primers for chloroplast genes, it is possible to make an estimate of the contamination by chloroplast DNA, which is normally determined as less than $0.5 \%$.

Note: Supplementary information is available via the HTML version of this article.

ACKNOWLEDGMENTS The Institute of Grassland and Environmental Research (IGER) is sponsored by the UK Biotechnology and Biological Sciences Research Council of the United Kingdom.

COMPETING INTERESTS STATEMENT The authors declare no competing financial interests.

Published online at http://www.natureprotocols.com

Rights and permissions information is available online at http://npg.nature.com/ reprintsandpermissions
1. Shizuya, H. et al. Cloning and stable maintenance of 300-kilobase-pair fragments of human DNA in Escherichia coli using an F-factor-based vector. Proc. Natl. Acad. Sci. USA 89, 8794-8797 (1992).

2. Woo, S.S., Jiang, J., Gill, B.S., Paterson, A.H. \& Wing, R.A. Construction and characterization of a bacterial artificial chromosome library of Sorghum bicolor. Nucleic Acids Res. 22, 4922-4931 (1994).

3. Zhang, H.B. \& Wu, C. BAC as tools for genome sequencing. Plant Physiol. Biochem. 39, 195-209 (2001).

4. Draper, J. et al. Brachypodium distachyon. A new model system for functional genomics in grasses. Plant Physiol. 127, 1539-1555 (2001). 
5. Christiansen, P., Andersen, C.H., Didion, T., Folling, M. \& Nielsen, K.K. A rapid and efficient transformation protocol for the grass Brachypodium distachyon. Plant Cell Rep. 23, 751-758 (2005).

6. Vogel, J.P., Garvin, D.F., Leong, O.M. \& Hayden, D.M. Agrobacterium-mediated transformation and inbred line development in the model grass Brachypodium distachyon. Plant Cell Tissue Organ Cult. 85, 199-211 (2006).

7. Vogel, J.P. et al. EST sequencing and phylogenetic analysis of the model grass Brachypodium distachyon. Theor. Appl. Genet. 113, 186-195 (2006).

8. Hasterok, R., Dulawa, J., Jenkins, G., Leggett, M. \& Langdon, T. Multi-substrate chromosome preparations for high throughput comparative FISH. BMC Biotechnol. 6, 20-24 (2006).

9. Jenkins, G. \& Hasterok, R. BAC 'landing' on chromosomes of Brachypodium distachyon for comparative genome alignment. Nat. Protoc. 2, 88-98 (2007).

10. Engvild, K.C. Mutagenesis of the model grass Brachypodium distachyon with sodium azide. Risø Report R-1510 http://www.risoe.dk/rispubl/BIO/ ris-r-1510.htm (2005).

11. Hasterok, R. et al. Alignment of the genomes of Brachypodium distachyon and temperate cereals and grasses using BAC landing with fluorescent in situ hybridization. Genetics 173, 349-362 (2006).

12. Farrar, K. et al. Construction of two Lolium perenne BAC libraries and identification of BACs containing candidate genes for disease resistance and forage quality. Mol. Breed. 19, 15-23 (2006).

13. Donnison, I.S. et al. Construction of a Festuca pratensis BAC library for map-based cloning in Festulolium substitution lines. Theor. Appl. Genet. 110, 846-851 (2005).

14. Calderini, 0. et al. Molecular cytogenetics and DNA sequence analysis of an apomixis-linked BAC in Paspalum simplex reveal a non pericentromere location and partial microcolinearity with rice. Theor. Appl. Genet. 112, 1179-1191 (2006).

15. Zhang, H.B., Zhao, X.P., Ding, X.L., Paterson, A.H. \& Wing, R.A. Preparation of megabase-size DNA from plant nuclei. Plant J. 7, 175-184 (1995).

16. Huo, N. et al. Construction and characterization of two BAC libraries from Brachypodium distachyon, a new model for grass genomics. Genome 49, 1099-1108 (2006).

17. Foote, T., Griffiths, S., Allouis, S. \& Moore, G. Construction and analysis of a BAC library in the grass Brachypodium sylviticum: its use as a tool to bridge the gap between rice and wheat in elucidating gene content. Funct. Integr. Genomics 4 26-33 (2004).

18. Chalhoub, B., Belcram, H. \& Caboche, M. Efficient cloning of plant genomes into bacterial artificial chromosome (BAC) libraries with larger and more uniform insert size. Plant Biotech. J. 2, 181-188 (2004).

19. Peterson, D.G., Tomkins, J.P., Frisch, D.A., Wing, R.A. \& Paterson, A.H. Construction of plant bacterial artificial chromosome (BAC) libraries: an illustrated guide 2nd Edition. (2002) http://www.mgel.msstate.edu/pubs/ bacman2.pdf.
20. Kim, U.J. et al. Construction and characterization of a human bacterial artificial chromosome library. Genomics 34, 213-218 (1996).

21. Frengen, E. et al. A modular, positive selection bacterial artificial chromosome vector with multiple cloning sites. Genomics 58, 250-253 (1999).

22. Wild, J., Hradecna, Z. \& Szybalski, W. Conditionally amplifiable BACs: switching from single-copy to high-copy vectors and genomic clones. Genome 12, 1434-1444 (2007).

23. Hamilton, C.M., Frary, A., Lewis, C. \& Tanksley, S.D. Stable transfer of intact high molecular weight DNA into plant chromosomes. Proc. Natl. Acad. Sci. USA 93, 9975-9979 (1996).

24. Takken, F.L. et al. A one-step method to convert vectors into binary vectors suited for Agrobacterium-mediated transformation. Curr. Genet. 45, 242-248 (2004).

25. Chang, Y.-L., Henriquez, X., Preuss, D., Copenhaver, G.P. \& Zhang, H.-B. A planttransformation-competent BIBAC library from the Arabidopsis thaliana Landsberg ecotype for functional and comparative genomics. Theor. Appl. Genet. 106 , 269-276 (2003).

26. Song, J., Bradeen, J.M., Naess, S.K., Helgeson, J.P. \& Jiang, J. BIBAC and TAC clones containing potato genomic DNA fragments larger than $100 \mathrm{~kb}$ are not stable in Agrobacterium. Theor. Appl. Genet. 107, 958-964 (2003).

27. She, K. So you want to work with giants: the BAC vector. BioTech. J. 1, 69-74 (2003).

28. Sheng, Y., Mancino, V. \& Birren, B. Transformation of Escherichia coli with large DNA molecules by electroporation. Nucleic Acids Res. 23, 1990-1996 (1995).

29. Bennett, M.D. \& Leitch, I.J. Nuclear DNA amounts in angiosperms: progress, problems and prospects. Ann. Bot. (Lond.) 95, 45-90 (2005).

30. Southern, E. Southern blotting. Nat. Protoc. 1, 518-525 (2006).

31. Sambrook, J. \& Russel, D.W. Molecular Cloning: A Laboratory Manual. (Cold Spring Harbor Laboratory Press, Cold Spring Harbor, New York, 2001).

32. O'Sullivan, D.M., Ripoll, P.J., Rodgers, M. \& Edwards, K.J. A maize bacterial artificial chromosome (BAC) library from the European flint inbred line $F_{2}$. Theor. Appl. Genet. 103, 425-432 (2001).

33. Whatling, C.A. \& Thomas, C.M. Pre electrophoresis of agarose plugs containing bacterial chromosomal DNA prepared for analysis by pulsed field gel electrophoresis can improve the clarity of restriction patterns. Anal. Biochem. 210, 98-101 (1993).

34. Ma, Z., Song, W., Sharp, P.J. \& Liu, C. Non-gridded library: a new approach for BAC (bacterial artificial chromosome) exploitation in hexaploid wheat (Triticum aestivum). Nucleic Acids Res. 28, e106 (2000).

35. Strong, S.J., Ohta, O., Litman, G.W. \& Amemiya, C.T. Marked improvement of PAC and $\mathrm{BAC}$ cloning is achieved using electroelution of pulsed-field gel-separated partial digests of genomic DNA. Nucleic Acids Res. 25, 3959-3961 (1997).

36. Zhu, H. \& Dean, R.A. A novel method for increasing the transformation efficiency of Escherichia coli-application for bacterial artificial chromosome library construction. Nucleic Acids Res. 27, 910-911 (1999).

37. Clarke, L. \& Carbon, J. A colony bank containing synthetic Col El hybrid plasmids representative of the entire $E$. coli genome. Cell 9, 91-99 (1976). 